\title{
Direct Colorimetric Detection of Hydrogen Peroxide Using 4-Nitrophenyl Boronic Acid or Its Pinacol Ester
}

\author{
Gregory Su, Yibin Wei, Maolin Guo \\ Department of Chemistry and Biochemistry, UMass Cranberry Health Research Center, \\ University of Massachusetts, Dartmouth, USA \\ E-mail:mguo@umassd.edu \\ Received October 19, 2011; revised November 23, 2011; accepted December 1, 2011
}

\begin{abstract}
A colorimetric method for the direct determination of hydrogen peroxide in aqueous solution is described. $\mathrm{H}_{2} \mathrm{O}_{2}$ stoichiometrically converts 4-nitrophenyl boronic acid or 4-nitrophenyl boronic acid pinacol ester into 4-nitrophenol, which can be quantified by measuring the absorption at $400 \mathrm{~nm}$ in neutral or basic media. The reactions proceed fast under basic conditions and complete in 2 minutes to at $\mathrm{pH} 11$ and $80^{\circ} \mathrm{C}$. The linear range for the colorimetric method extends beyond 1.0 to $40 \mu \mathrm{M} \mathrm{H}_{2} \mathrm{O}_{2}$, and the limit of detection is $\sim 1.0 \mu \mathrm{M}$ $\mathrm{H}_{2} \mathrm{O}_{2}$. This method offers a convenient and practical process for rapid determination of hydrogen peroxide in aqueous media. Compared to many other techniques in $\mathrm{H}_{2} \mathrm{O}_{2}$ detection, this process is a direct measurement of $\mathrm{H}_{2} \mathrm{O}_{2}$, and is relatively unaffected by the presence of various salts, metal ions and the chelator EDTA.
\end{abstract}

Keywords: Hydrogen Peroxide Detection, 4-Nitrophenyl Boronic Acid, 4-Nitrophenyl Boronic Acid Pinacol Ester, 4-Nitrophenol, Colorimetric Method

\section{Introduction}

Hydrogen peroxide is an integral part of atmospheric chemistry and biological systems. In the atmosphere, it is an oxidant that is produced from the combination of hydroperoxyl radicals $\left(\mathrm{HO}_{2} \cdot\right)$ and their hydrated form [1]. Hydrogen peroxide is exceptionally soluble in water and it is thought to be the most efficient oxidant in the formation of $\mathrm{H}_{2} \mathrm{SO}_{4}$ from dissolved $\mathrm{SO}_{2}$ [1]. This implies that hydrogen peroxide could have some role in the acidity of rainwater. Hydroperoxides are significant atmospheric sinks and temporary reservoirs for $\mathrm{HO}_{\mathrm{x}}$. and $\mathrm{RO}_{\mathrm{x}}$ ' radicals $[1,2]$. In biological systems, $\mathrm{H}_{2} \mathrm{O}_{2}$ is produced in reactions catalyzed by numerous bio-enzymes. It has also come forth as a recently recognized messenger in cellular signal transduction [3]. At high concentrations, aqueous solutions of hydrogen peroxide can irritate the eye and other organs, in addition to being a mutagen [4]. In the presence of redox active metal ions, $\mathrm{H}_{2} \mathrm{O}_{2}$ can be converted to $\mathrm{OH} \cdot$ radicals via Fenton reactions [5]:

$$
\mathrm{Fe}^{\mathrm{II}}\left(\mathrm{Cu}^{\mathrm{I}}\right)+\mathrm{H}_{2} \mathrm{O}_{2} \rightarrow \mathrm{Fe}^{\mathrm{III}}\left(\mathrm{Cu}^{\mathrm{II}}\right)+\mathrm{OH}^{-}+\mathrm{OH} \bullet
$$

The extremely reactive hydroxyl radical $(\mathrm{OH}$, half-life $\approx 1 \mathrm{~ns}$ ) is highly toxic to cells and contributes to neurodegenerative diseases and the aging process. $\mathrm{Fe}^{\mathrm{III}}$ can be reduced to $\mathrm{Fe}^{\mathrm{II}}$ by cellular reductants such as hydroascorbate $\left(\mathrm{AscH}^{-}\right)$and nictotineamide adenine dinucleotide (NADH), making the Fenton reactions catalytic.

More recently, peroxide based explosives have been involved in some recent terrorism incidents [6]. Thus simple and sensitive peroxide detection is also important in counterterrorism efforts. Various methods have been developed for $\mathrm{H}_{2} \mathrm{O}_{2}$ detection [1,7-14]. The horseradish peroxidase (HRP)-catalyzed reaction is one of the most popular enzymatic assays used for determination of $\mathrm{H}_{2} \mathrm{O}_{2}$ [8], however, this reaction is quenched or restrained from cations, surfactants, and organic solvents, and the reagents are expensive. Other methods for $\mathrm{H}_{2} \mathrm{O}_{2}$ determination include HPLC, colorimetric methods, amperometry and chemiluminescence. Titanium-based assays (Ti-PAPS reagents) were developed in the 1980's for spectrophotometric detection of $\mathrm{H}_{2} \mathrm{O}_{2}$ [9]. The Fox assay was developed in 1990's based on ferrous ion oxidation in the presence of the ferric ion indicator xylenol orange under acidic conditions [10]. Tanner and co-workers investigated the detection of $\mathrm{H}_{2} \mathrm{O}_{2}$ through a reaction with pyridine-2,6-dicarboxylic acid and vanadate $(\mathrm{V})$ in acidic solution to form a orange-red complex chelate complex, oxo-peroxo-pyridine-2,6-dicarboxylato vanadate (V) detectable at $432 \mathrm{~nm}$ [11]. Recently, Luo and 
co-workers developed a detection method based on oxidation of methyl orange using an iron-catalyzed Fenton reaction system under acidic conditions [12]. Other methods, such as fluorescent probes (e.g. Peroxy Green 1 and Peroxy Crimson 1) have recently been developed to monitor hydrogen peroxide production in living cells [13]. Chemiluminescence methods have also been developed recently $[4,14]$. These methods are highly sensitive, but they are limited by complicated apparatus setup and sensor preparation, interferences from metal ions, and inhibition from chelators, e.g. EDTA [2,4,14].

Despite the numerous methods for hydrogen peroxide detection available, it is still of interest to find a simple, direct, inexpensive technique that requires simple instrumentation and is free of numerous interferences. It has been shown that $\mathrm{H}_{2} \mathrm{O}_{2}$ may convert aromatic boronic acid or their pinacol esters to a hydroxyl group $[13,15,16,17]$. Based on the same principle, 4-nitrophenyl-bornic acid or 4-nitrophenylboronic acid pinacol ester may react with $\mathrm{H}_{2} \mathrm{O}_{2}$ to produce 4-nitrophenol (Scheme 1), a yellow colored compound detectable at $400 \mathrm{~nm}$. Here we have investigated the possibility of utilizing 4-nitrophenylbornic acid or its pinacol ester to deter- mine $\mathrm{H}_{2} \mathrm{O}_{2}$ directly in aqueous media.

\section{Experimental}

\subsection{Reagents and Apparatus}

4-nitrophenylbornic acid and 4-nitrophenylboronic acid pinacol ester were purchased from Boron Molecular Company (Raleigh, NC). Hydrogen peroxide was purchased from Sigma-Aldrich Corp. (St. Louis, MO, USA). All other chemicals are commercially available and used without further purification.

UV-Vis spectroscopic studies were performed on a Perkin Elmer Lambda 25 Spectrophotometer. NMR spectra were recorded on a Bruker AC-300 NMR spectrometer. The $\mathrm{pH}$ value of all buffer solutions was determined with a Corning $\mathrm{pH}$ meter equipped with a Sigma-Aldrich micro combination electrode calibrated with Aldrich buffer solutions.

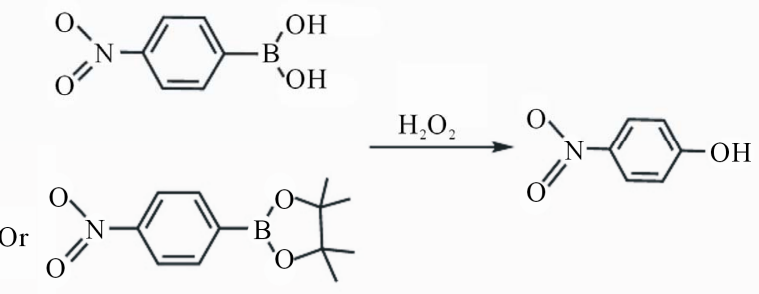

Scheme 1. 4-Nitrophenylbornic acid or its pinacol ester reacts with $\mathrm{H}_{2} \mathrm{O}_{2}$ to produce 4-nitrophenol.

\subsection{Specifications of Reactions between $\mathrm{H}_{2} \mathrm{O}_{2}$ and 4-Nitrophenyl Boronic Acid or 4-Nitrophenyl Boronic Acid Pinacol Ester}

Stock solutions of 4-Nitrophenyl boronic acid (1.0 mM) and 4-Nitrophenyl boronic acid pinacol ester $(1.0 \mathrm{mM})$ were prepared in methanol. These were then diluted in $20 \mathrm{mM}$ Tris- $\mathrm{HCl}$ buffer ( $\mathrm{pH}$ 7.27) to make several $100 \mu \mathrm{M}$ samples. $\mathrm{H}_{2} \mathrm{O}_{2}$ was then added to the samples to create a final $\mathrm{H}_{2} \mathrm{O}_{2}$ concentration of $1.0 \mathrm{mM}$. The reactions were then monitored by UV-vis spectrometer at 10, 20, 30, 60, 90, 120, 150 and 180 minutes, respectively. Similar re- actions were also investigated at $\mathrm{pH}$ values of $6.91,8.06,9.04,9.96$ and 10.95 in $20 \mathrm{mM}$ Tris- $\mathrm{HCl}$ buffers, after incubation for 60 minutes at room temperature $\left(25^{\circ} \mathrm{C}\right)$.

More detailed studies were carried out at $\mathrm{pH} 8$ and $\mathrm{pH}$ 11 and at various temperatures. $20 \mathrm{mM}$ Tris- $\mathrm{HCl}$ buffer, $\mathrm{pH} 8.06$ was used for the $\mathrm{pH} 8$ studies. 4-Nitrophenyl boronic acid $(100 \mu \mathrm{M})$ or 4-Nitrophenyl boronic acid pinacol ester was mixed with $1.0 \mathrm{mM} \mathrm{H}_{2} \mathrm{O}_{2}$ in the buffer. Samples were incubated in sealed tubes for varying amounts of time at $37^{\circ} \mathrm{C}$, to simulate physiological relevant conditions, and the kinetics were monitored by a UV-vis spectrometer. The same was done for $\mathrm{pH} 11$, but instead $1.0 \mathrm{mM} \mathrm{NaOH}(\mathrm{pH} 11)$ was used. Analogous procedures were also carried out at $23^{\circ} \mathrm{C}, 55^{\circ} \mathrm{C}$ and $80^{\circ} \mathrm{C}$.

\subsection{Determining the Rate Constants and Activation Energy}

The kinetic data at different temperatures was used to estimate the rate constants and activation energy of the reactions of 4-nitrophenylboronic acid and 4-nitrophenylboronic acid pinacol ester with $\mathrm{H}_{2} \mathrm{O}_{2}$. For a first order reaction, a plot of the natural log of the reactant concentration vs. time will yield a linear relationship. At 10-fold excess of $\mathrm{H}_{2} \mathrm{O}_{2}$, the reaction is pseudo 1 st order. The initial concentration of reactant, $\left[\mathrm{A}_{0}\right]$, is proportional to the concentration of product, $\left[\mathrm{P}_{\mathrm{f}}\right]$, after the reaction has completed since nearly all of the reactant has been converted to product,

$$
\left[A_{0}\right] \propto\left[P_{f}\right]
$$

In this way, the concentration of reactant at time $t$ is proportional to $\left[P_{f}\right]$ minus the concentration of product at time $\mathrm{t},[P]$,

$$
[A] \propto\left[P_{f}\right]-[P]
$$

Using these substitutions, the first order rate law $\ln \left([A] /\left[A_{0}\right]\right)=-k t$ can be written as,

$$
\ln \left(\frac{\left[P_{f}\right]-[P]}{\left[P_{f}\right]}\right)=-k t \text {. }
$$


The concentration of product is comparative to the absorbance, so $\left[\mathrm{P}_{\mathrm{f}}\right]$ can be related to the absorbance of the highest peak of the product at $400 \mathrm{~nm}$, when the reaction has reached completion. The $[\mathrm{P}]$ values can be interpreted as the absorbance at $400 \mathrm{~nm}$ for the intermediate times that is all the peaks below the highest. In this way, the rate constants for the reactions at different temperatures can be determined by plotting

$\ln \left(\left(\left[P_{f}\right]-[P]\right) /\left[P_{f}\right]\right)$ vs time, where the rate constant $\mathrm{k}$ is the negative of the resulting slope.

\subsection{Standard Curves}

Standard curves for $\mathrm{H}_{2} \mathrm{O}_{2}$ were determined for both 4-Nitrophenyl boronic acid and 4-Nitrophenyl boronic acid pinacol ester at $\mathrm{pH} 8$ and $\mathrm{pH} 11$. In each case, the concentration of boronic compounds was $50 \mu \mathrm{M}$, and the $\mathrm{H}_{2} \mathrm{O}_{2}$ concentrations were $0.5,1,2,5,10,20$ and $40 \mu \mathrm{M}$. For the trials at $\mathrm{pH} 8(20 \mathrm{mM}$ Tris- $\mathrm{HCl}$ buffer, $\mathrm{pH} 8.06)$, the samples were incubated at $37^{\circ} \mathrm{C}$ for 2 hours and absorbances at $400 \mathrm{~nm}$ were recorded. For the $\mathrm{pH} 11$ tests, the samples were incubated in $1 \mathrm{mM} \mathrm{NaOH}$ at $80^{\circ} \mathrm{C}$ for 10 minutes and the absorptions at $400 \mathrm{~nm}$ were recorded.

\subsection{Interferences from Salts, Reducing Agents, Metal Ions, and Chelators}

The effect of varying concentrations of several salts, $\mathrm{NaCl}$, $\mathrm{K}_{2} \mathrm{HPO}_{4}, \mathrm{~K}_{2} \mathrm{SO}_{4}$ and $\mathrm{KNO}_{3}$, on the $\mathrm{H}_{2} \mathrm{O}_{2}$ detection was tested. The samples, each containing $50 \mu \mathrm{M}$ of 4-Nitrophenyl boronic acid (or 4-Nitrophenyl boronic acid pinacol ester), $40 \mu \mathrm{M}$ of $\mathrm{H}_{2} \mathrm{O}_{2}$ and a salt concentra- tion (0 $\mu \mathrm{M}, 10 \mu \mathrm{M}, 100 \mu \mathrm{M}, 500 \mu \mathrm{M}, 1 \mathrm{mM}$ or $10 \mathrm{mM})$ were incubated at $\mathrm{pH} 11(1 \mathrm{mM} \mathrm{NaOH})$ and $80^{\circ} \mathrm{C}$ for $10 \mathrm{~min}$ utes, after which, the absorbance at $400 \mathrm{~nm}$ was recorded.

A similar procedure was used to test the interference from several metal ions, ascorbic acid, glutathione (GSH) and the chelator EDTA.

\section{Results and Discussion}

\subsection{Kinetics of the Reactions of 4-Nitrophenyl Boronic Acid or Its Pinacol Ester with $\mathrm{H}_{2} \mathrm{O}_{2}$}

The reaction of 4-nitrophenylboronic acid or 4-nitrophenylboronic acid pinacol ester with $\mathrm{H}_{2} \mathrm{O}_{2}$ were monitored by UV-vis spectroscopy in $100 \mu \mathrm{M}$ solution, $\mathrm{pH}$ 7.27. The 4-nitrophenylboronic acid and 4-nitrophenylboronic acid pinacol ester are colorless and displayed absorption $\left(\lambda_{\max }\right.$ at $290 \mathrm{~nm}$ ) in UV region only. After the addition of $\mathrm{H}_{2} \mathrm{O}_{2}$, the original absorption peak for 4-nitrophenylboronic acid pinacol ester (Figure 1) decreased intensity while a new peak centered at $405 \mathrm{~nm}$ appeared

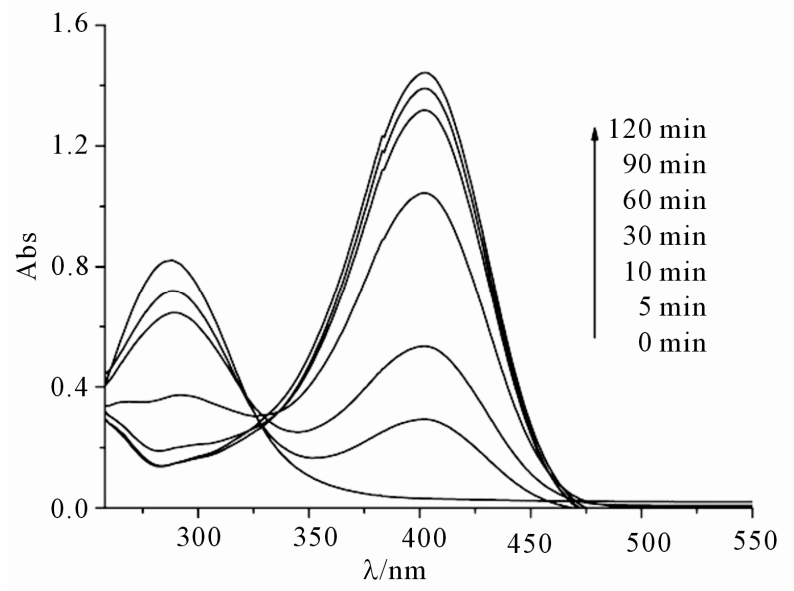

Figure 1. Kinetics of UV-vis spectra of $100 \quad \mu M$ 4-Nitrophenyl boronicacid pinacol ester reaction with $\mathrm{H}_{2} \mathrm{O}_{2}$

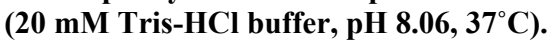

and increased in intensity with an isobestic point at 330 $\mathrm{nm}$, and the color of the solution changed from colorless to yellow, implying the formation of 4-nitrophenol. The rate constant was determined to be $0.0586 \mathrm{~s}^{-1}$. Similar changes were observed for 4-nitro-phenylboronic acid.

To investigate whether the conversion is a clean chemistry and to confirm that 4-nitrophenol is the product, the reaction processes were monitored by $1 \mathrm{H}$ NMR spectroscopy. As shown in Figure 2, when $\mathrm{H}_{2} \mathrm{O}_{2}$ was added to 4-nitrophenyl boronic acid, the original proton resonances at 8.19 and $8.21 \mathrm{ppm}$ (doublet, meta) and $7.90 \mathrm{ppm}$ (broad, ortho) decreased in intensity with the later split into two peaks at 7.92 and $7.95 \mathrm{ppm}$. The splitting is probably due to the breaking of the hydrogen bonds in the 4-nitrophenyl boronic acid dimer [18]. Meanwhile, new peaks characteristic for 4-nitrophenol emerged and grew in intensity, at the expense of the resonances of the 4-nitrophenyl boronic acid. After 240 min, the 1H NMR spectrum (Figure 2(c)) is identical to that of the 4-nitrophenol standard (Figure 2(d)). This clearly confirmed that 4-nitrophenyl boronic acid had been cleanly converted to 4-nitrophenol. Similar experiments performed with 4-nitrophenyl boronic acid pinacol ester demonstrated a clean conversion to 4-nitrophenol by $\mathrm{H}_{2} \mathrm{O}_{2}$ but at a slower rate.

\section{2. $\mathrm{pH} /$ Temperature Dependence}

The $\mathrm{pH}$ dependence of the conversion of the boronic acid compounds by $\mathrm{H}_{2} \mathrm{O}_{2}$ was investigated over a $\mathrm{pH}$ range of 6.9 to 11.8 after incubation at room temperature $\left(25^{\circ} \mathrm{C}\right)$ for $60 \mathrm{~min}$. As shown in Figure 3, improved conversion was achieved at more basic $\mathrm{pH}$ values with the best $\mathrm{pH}$ at $\sim 11$ for both the 4-nitrophenyl boronic acid and its pinacol ester. 


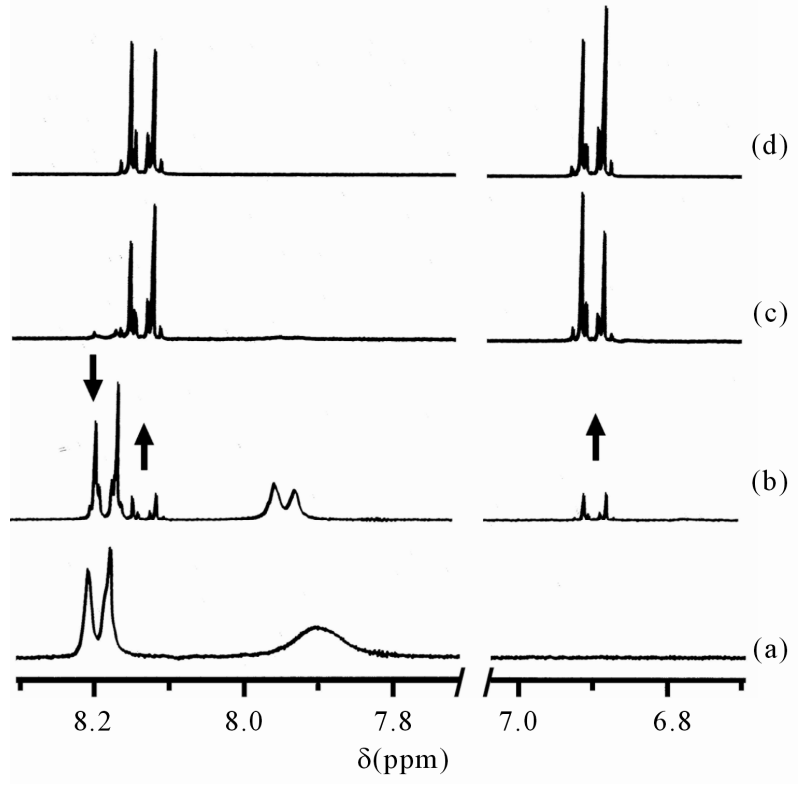

Figure 2. ${ }^{1} \mathrm{H}-\mathrm{NMR}$ spectra of (a) $10 \mathrm{mM}$ 4-Nitrophenyl boronic acid in $\mathrm{d}^{4}-\mathrm{MeOH}$, the mixture of 4-Nitrophenyl boronicacid $(10 \mathrm{mM})$ and $\mathrm{H}_{2} \mathrm{O}_{2}(100 \mathrm{mM})$ incubated for 60 min (b) and $240 \mathrm{~min}$ (c), and (d) $10 \mathrm{mM}$ 4-nitrophenol in $\mathrm{d}^{4}-\mathrm{MeOH}$.

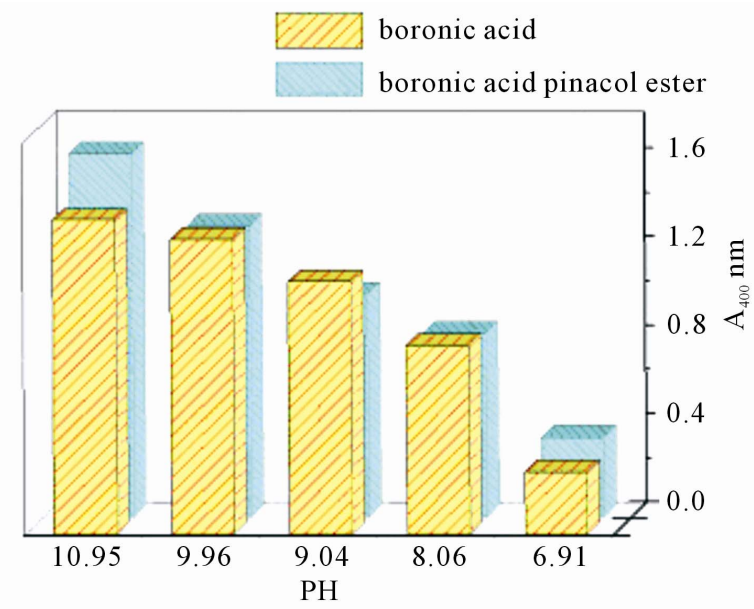

Figure 3. pH profile of absorbance $(400 \mathrm{~nm})$ of the reaction of $\mathrm{H}_{2} \mathrm{O}_{2}$ incubated with 4-Nitrophenyl boronic acid or its pinacol ester $(100 \mu \mathrm{M})$ for $60 \mathrm{~min}$.

The effect of temperature was also investigated. As expected, the reaction rate increased with increasing temperature. At $\mathrm{pH} 11$ and $37^{\circ} \mathrm{C}$, the reaction reached completion in 60 minutes, about half the time as the room temperature and $\mathrm{pH} 8$ reaction. Increasing the temperature further to $55^{\circ} \mathrm{C}$ decreased reaction time to about 15 minutes. And at $80^{\circ} \mathrm{C}$, the reaction finished within 2 minutes. The rate constants for 4-nitrophenylboronic acid and its pinacol ester at pH 11 and varying temperatures were determined and shown in Table 1.
Table 1. Rate constants for 4-nitrophenyl boronic acid and its pinacol ester at $\mathrm{pH} 11\left(\mathrm{~s}^{-1}\right)$.

\begin{tabular}{ccccc}
\hline & $25^{\circ} \mathrm{C}$ & $37^{\circ} \mathrm{C}$ & $55^{\circ} \mathrm{C}$ & $80^{\circ} \mathrm{C}$ \\
\hline $\begin{array}{c}\text { 4-Nitrophenylboronic } \\
\text { acid }\end{array}$ & 0.0315 & 0.1318 & 0.2977 & $\mathrm{ND}$ \\
$\begin{array}{c}\text { 4-Nitrophenylboronic } \\
\text { acid pinacol ester }\end{array}$ & 0.0586 & 0.144 & 0.3292 & 0.7155 \\
\hline
\end{tabular}

The rate constants at different temperatures were used to estimate the activation energy. According to the Arrhenius equation, $k=A \mathrm{e}^{E_{a} / R T}$ [19], a plot of $\ln (k)$ vs. $1 / \mathrm{T}$ will give a linear plot with slope of $-E_{a} / R$. The activation energies at $\mathrm{pH} 11$ were calculated to be 82.4 $\mathrm{kJ} / \mathrm{mol}$ and $59.5 \mathrm{~kJ} / \mathrm{mol}$ for 4-nitrophenylboronic acid pinacol ester and 4-nitrophenylboronic acid, respectively.

\subsection{Standard Curves and Detection Limit}

Experiments were performed with $50 \mu \mathrm{M}$ 4-Nitrophenyl boronic acid or the boronic acid ester and a range of $\mathrm{H}_{2} \mathrm{O}_{2}$ concentrations from $0.5 \mu \mathrm{M}$ to $40 \mu \mathrm{M}$. A linear trend was observed for $\mathrm{H}_{2} \mathrm{O}_{2}$ concentration in the range of $1 \mu \mathrm{M}$ to $40 \mu \mathrm{M}$ (Figure 4 ), indicating reliable detection. Similar tests were carried out for physiological conditions, $\mathrm{pH} 8$ and $37^{\circ} \mathrm{C}$, which exhibited comparable results. The 4-Nitrophenyl boronic acid reaction with $\mathrm{H}_{2} \mathrm{O}_{2}$ displayed the potential to be accurate to $\mathrm{a}\left[\mathrm{H}_{2} \mathrm{O}_{2}\right]$ of about $1 \mu \mathrm{M}$.

\subsection{Interference}

It is of interest to study the ability of 4-Nitrophenyl boronic acid or its pinacol ester to maintain accurate detection of $\mathrm{H}_{2} \mathrm{O}_{2}$ in the presence of other compounds. Several

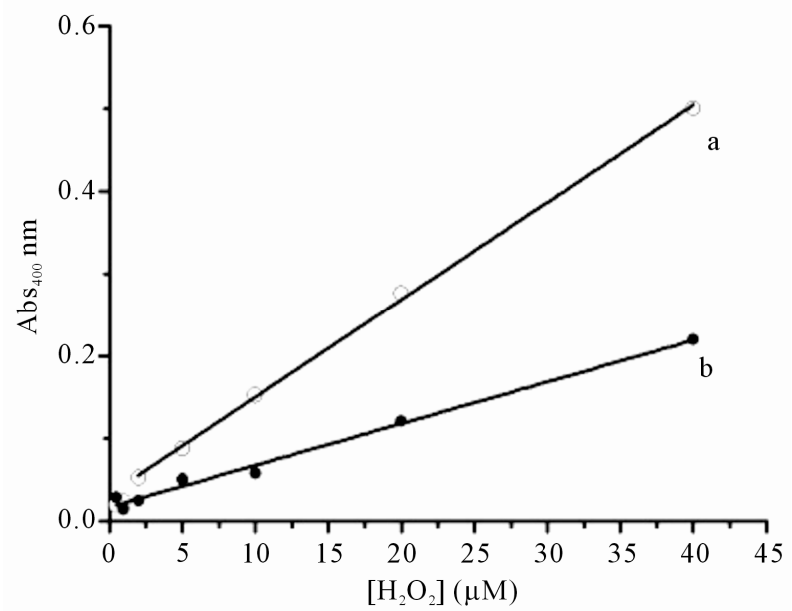

Figure 4. Standard curves of detection of $\mathrm{H}_{2} \mathrm{O}_{2}$ with (a) $50 \mu \mathrm{M}$ 4-Nitrophenyl boronic acid pinacol ester at $\mathrm{pH} 11,37^{\circ} \mathrm{C}$ or with

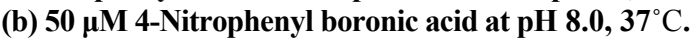


potential interfering compounds were investigated, including various salts, reductants, metal ions, and chelators. The salts ( 0 to $10 \mathrm{mM}$ ) NaCl, $\mathrm{K}_{2} \mathrm{HPO}_{4}, \mathrm{~K}_{2} \mathrm{SO}_{4}$, and $\mathrm{KNO}_{3}$ were all tested with the reaction and, as expected, showed no significant affect on the ability to detect $\mathrm{H}_{2} \mathrm{O}_{2}$.

The effect of the chelator EDTA was investigated. It appears that at low concentrations EDTA does not have a significant effect on $\mathrm{H}_{2} \mathrm{O}_{2}$ detection (Figure 5). The absorbance remained relatively steady, and began to decrease slightly only at the higher concentrations of about $1 \mathrm{mM}$ and above. At $10 \mathrm{mM}$ EDTA, the absorbance decreased by ca. $34 \%$. This is a significant improvement over the chemiluminescence method where EDTA significantly inhibits detection at the $20 \mu \mathrm{M}$ level and above, reducing the signal to near zero by $100 \mu \mathrm{M}$ [2].

The influence of transition metal ions was examined by analyzing the absorbance deviation at $400 \mathrm{~nm}$ of a solution of $50 \mu \mathrm{M}$ boronic acid or its picanol ester incubated with $50 \mu \mathrm{M} \mathrm{H}_{2} \mathrm{O}_{2}$ for $45 \mathrm{~min}$ at $\mathrm{pH} \mathrm{11.0,} \mathrm{to} \mathrm{which}$ varying concentrations of $\mathrm{Pb}^{2+}, \mathrm{Mn}^{2+}, \mathrm{Ni}^{2+}, \mathrm{Fe}^{3+}, \mathrm{Cu}^{2+}$ and $\mathrm{Zn}^{2+}$ was added. As shown in Figure 6, the interfereence caused by $\mathrm{Pb}^{2+}$ is almost negligible under all tested concentrations from $5 \mu \mathrm{M}$ to $50 \mu \mathrm{M}$. Ions of $\mathrm{Mn}^{2+}, \mathrm{Ni}^{2+}$ and $\mathrm{Cu}^{2+}$ show little interference up to concentration of $20 \mu \mathrm{M}$; however, a decrease in absorbance by ca. $12 \%$ was observed at $50 \mu \mathrm{M}$. $\mathrm{Zn}^{2+}$ demonstrated mild interference on 4-Nitrophenyl boronic acid or its pinacol ester detection (increasing absorbance by ca. $2 \%-5 \%$ ) in the tested concentration range. $\mathrm{Fe}^{3+}$ displayed more serious interference in both the systems with the absorbance increased by ca. $11 \%$ at an $\mathrm{Fe}^{3+}$ concentration of $20 \mu \mathrm{M}$, probably due to the absorbance from iron-hydroxide complexes formed in the solution.

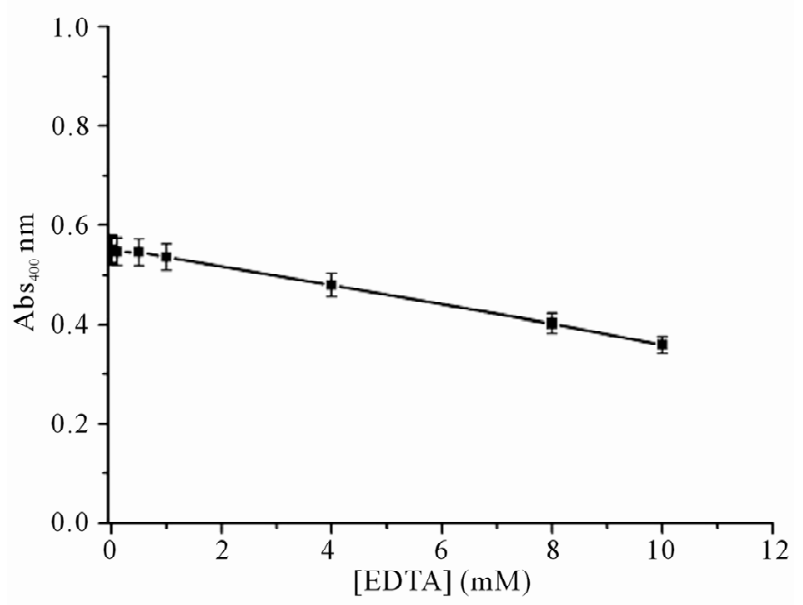

Figure 5. Effect of EDTA at varying concentrations on the absorbance $(400 \mathrm{~nm})$ of solution of $50 \mu \mathrm{M}$ boronic acid and $40 \mu \mathrm{M} \mathrm{H}_{2} \mathrm{O}_{2}$.

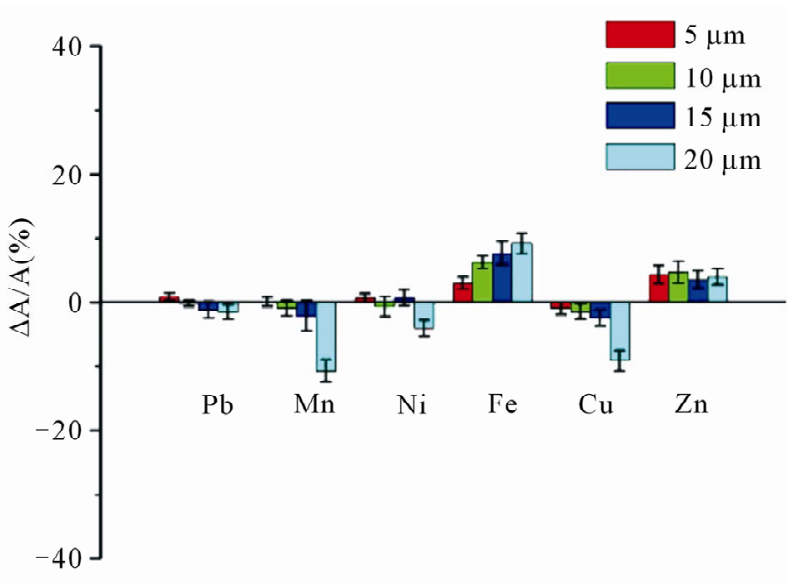

(a)

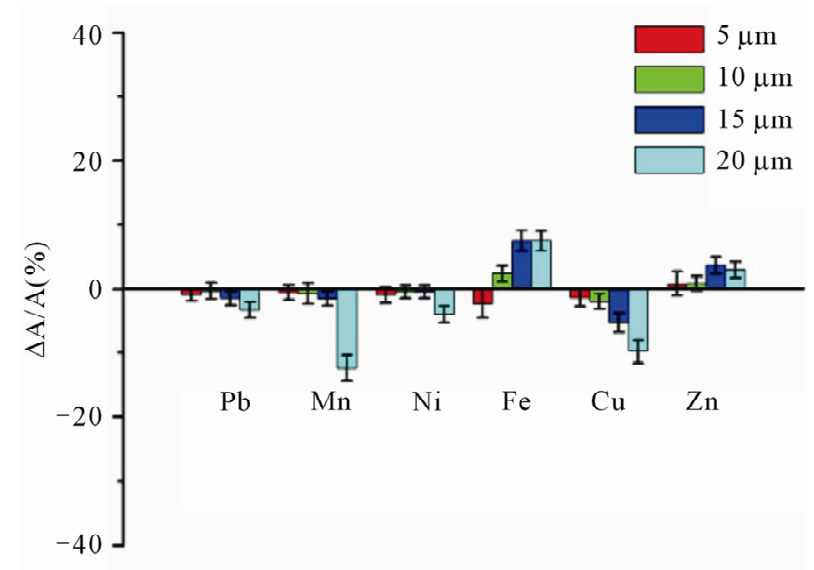

(b)

Figure 6. Interference of $\mathrm{Pb}^{2+}, \mathrm{Mn}^{2+}, \mathrm{Ni}^{2+}, \mathrm{Fe}^{3+}, \mathrm{Cu}^{2+}$ and $\mathrm{Zn}^{2+}$ on $\mathrm{H}_{2} \mathrm{O}_{2}$ detection achieved with 4-Nitrophenyl boronic acid (a) and its pinacol ester (b) at pH 11.

\section{Conclusions}

The reaction of 4-nitrophenyl boronic acid or 4-nitrophenyl boronic acid pinacol ester with hydrogen peroxide is a useful method for hydrogen peroxide detection. The reaction runs under neutral to basic conditions, with maximum kinetics at $\mathrm{pH} 11$ and high temperatures. This method is able to detect $\mathrm{H}_{2} \mathrm{O}_{2}$ to a concentration of about $1 \mu \mathrm{M}$. It is unaffected by the presence of various salts, or low levels of the metal ions of $\mathrm{Pb}^{2+}, \mathrm{Ni}^{2+}, \mathrm{Cu}^{2+}$ and $\mathrm{Zn}^{2+}$, $\mathrm{Mn}^{2+}$ and $\mathrm{Fe}^{3+}$, and the chelator EDTA. The reaction of boronic acid with $\mathrm{H}_{2} \mathrm{O}_{2}$ is a direct measurement of $\mathrm{H}_{2} \mathrm{O}_{2}$ as compared to many other methods; it requires only simple instrumentation and preparation, and is very inexpensive. It could prove useful in detecting $\mathrm{H}_{2} \mathrm{O}_{2}$ in the environment and in biological systems and this chemistry may be harnessed to develop novel devices for $\mathrm{H}_{2} \mathrm{O}_{2}$ detection. 


\section{Acknowledgements}

We thank the University of Massachusetts S \& T Initiative and Cranberry Research Program for funding. This publication was made possible by Grant Number 1 R21 AT002743-02 from the National Center for Com- plementary and Alternative Medicine (NCCAM). Its contents are solely the responsibility of the authors and do not necessarily represent the official views of the NCCAM, or the National Institutes of Health.

\section{References}

[1] Y. Zuo and J. Hoigné, "Evidence for Photochemical Formation of $\mathrm{H}_{2} \mathrm{O}_{2}$ and Oxidation of $\mathrm{SO}_{2}$ in Authentic Fog Water," Science, Vol. 260, No. 5104, 1992, pp. 7173. doi:10.1126/science.260.5104.71

[2] A. Tahirovic, A. Copra, E. Omanovic-Miklicanin and K. Kalcher, "A Chemiluminescence Sensor for the Determination of Hydrogen Peroxide," Talanta, Vol. 72, No. 4, 2007, pp. 1378-1385. doi:10.1016/j.talanta.2007.01.072

[3] G. Georgiou and L. Masip, “An Overoxidation Journey with a Return Ticket," Science, Vol. 300, No. 5619, 2003, pp. 592-594. doi:10.1126/science. 1084976

[4] A. Navas Diaz, F. G. Sanchez, M. C. Torijas and J. Lovillo, "Chemiluminescent Lipase Determination Based on the Enhanced Luminol $/ \mathrm{H}_{2} \mathrm{O}_{2}$ /horsedadish Peroxidase/ Fluorescein Diacetate Energy Transfter System," Fresenius' Journal of Analytical Chemistry, Vol. 365, 1999, pp. 537-540. doi:10.1007/s002160051518

[5] H. J. H. Fenton, "Oxidation of Tartaric Acid in Presence of Iron," Journal of the Chemical Society, Vol. 65, 1894, pp. 899-910. doi:10.1039/ct8946500899

[6] B. Halford, "Explosives Detection: Sensor Capitalizes on Contrasts in Redox Chemistry," Chemical \& Engineering News, Vol. 86, No. 11, 2008, p. 10. doi:10.1021/cen-v086n011.p010

[7] F. Sauer, S. Limbach and G. K. Moortgat, "Measurements of Hydrogen Peroxide and Individual Organic Peroxides in the Marine Troposphere," Atmospheric Environment, Vol. 31, No. 8, 1997, pp. 1173-1184. doi:10.1016/S1352-2310(96)00289-0

[8] J. Tang, B. Wang, Z. Wu, X. Han, S. Dong and E. Wang, "Lipid Membrane Immobilized Jorseradish Peroxidase Biosensor for Amperometric Determination of Hydrogen Peroxide," Biosensors \& Bioelectronics, Vol. 18, No. 7, 2003, pp. 867-872. doi:10.1016/S0956-5663(02)00148-3
[9] C. Matsubara, K. Kudo, T. Kawashita and K. Takamura, "Spectrophotometric Determination of Hydrogen Peroxide with Titanium 2-((5-Bromopyridyl)azo)-5-(N-Propyl-N-Sulfopropylamino)Phenol Reagent and Its Application to the Determination of Serum Glucose Using Glucose Oxidase," Analytical Chemistry, Vol. 57, No. 6, 1985, pp. 1107-1109. doi:10.1021/ac00283a032

[10] S. Wolff, "Ferrous Ion Oxidation in Presence of Ferric Ion Indicator Xylenol Orange for Measurement of Hydroperoxides," Methods in Enzymology, Vol. 233, 1994, pp. 182-189. doi:10.1016/S0076-6879(94)33021-2

[11] P. A. Tanner and A. Y. S. Wong, "Spectrophotometric Determination of Hydrogen Peroxide in Rainwater," Analytica Chimica Acta, Vol. 370, No. 2-3, 1998, pp. 279287. doi:10.1016/S0003-2670(98)00273-6

[12] W. Luo, M. E. Abbas, L. Zhu, K. Deng and H. Tang, "Rapid Quantitative Determination of Hydrogen Peroxide by Oxidation Decolorization of Methyl Orange Using a Fenton Reaction System," Analytica Chimica Acta, Vol. 629, No. 1-2, 2008, pp. 1-5. doi:10.1016/j.aca.2008.09.009

[13] E. W. Miller, O. Tulyanthan, E. Y. Isacoff and C. J. Chang, "Molecular Imaging of Hydrogen Peroxide Produced for Cell Signaling," Nature Chemical Biology, Vol. 3, 2007, pp. 263-267. doi:10.1038/nchembio871

[14] M. J. Navas, A. M. Jimenez and G. Galan, “Air Analysis: Determination of Hydrogen Peroxide by Chemiluminescence," Atmospheric Environment, Vol. 33, No. 14, 1999, pp. 2279-2283. doi:10.1016/S1352-2310(98)00117-4

[15] Y. Wei and M. Guo, "Hydrogen Peroxide Triggered Prochelator Activation, Subsequent Metal Chelation, and Attenuation of the Fenton Reaction," Angewandte Chemie International Edition, Vol. 46, No. 25, 2007, pp. 4722-4725. doi:10.1002/anie.200604859

[16] Y. Wei and M. Guo, "A Novel $\mathrm{H}_{2} \mathrm{O}_{2}$-Triggered AntiFenton Fluorescent Prochelator Excitable with Visible Light," Chemical Communications, No. 11, 2009, pp. 1413-1415.

[17] Y. Wei, Y. Zhang, Z. Liu and M. Guo, "A Novel Profluorescent Probe for Detecting Oxidative Stress Induced by Metal and $\mathrm{H}_{2} \mathrm{O}_{2}$ in Living Cells," Chemical Communications, 2010, Vol. 46, pp. 4472-4474. doi: $10.1039 / \mathrm{c} 000254 \mathrm{~b}$

[18] D. G. Hall, "Boronic Acids: Preparation, Applications in Organic Synthesis and Medicine," 1st Edition, WileyVCH Verlag GmbH \& Co. KGaA, Weinheim, 2005.

[19] P. Atkins and J. dePaula, "Physical Chemistry," 8th Edition, W. H. Freeman, Gordonsville, 2006. 